\title{
PENGARUH STRATEGI KOMUNIKASI TERHADAP JUMLAH KONSUMEN PADA DITA TOUR TRAVEL DI MADIUN
}

\author{
Lita Widiyanti \\ Mahasiswa Prodi Pendidikan Ekonomi IKIP PGRI Madiun
}

\begin{abstract}
Abstrak: Tujuan dari penelitian ini adalah mengetahui strategi komunikasi pada "Tour Travel Dita" di Madiun. Untuk mengetahui jumlah konsumen "Travel Tour Dita" di Madiun juga tahu ada strategi komunikasi pengaruh kuantitas konsumen "Travel Dita Tour" di Madiun.Determination sampel dalam penelitian ini menggunakan sampel jenuh 36 Bulan, dimulai dari Bulan Januari 2010 sampai Bulan Desember 2012. pengumpulan data menggunakan dokumentasi. Data analisis yang digunakan korelasi dan uji regresi metode statistik untuk menguji hipotesis yang diajukan dalam hasil study.The ini strategi komunikasi penelitian menunjukkan berkorelasi juga positif pengaruh untuk jumlah konsumen pada "Tour Travel Dita" di Madiun. Hal ini obstained dari uji korelasi menunjukkan nilai rhitung adalah 0.769 sedangkan rtabel 0329, pada nilai lain Sighit adalah 0,000 sedangkan Sigprob 0,05 . Hal ini berarti bahwa nilai rhitung $\geq \operatorname{rtabel}(0.769 \geq 0.329)$ atau Sighit $\leq$ Sigprob $(0,000 \leq 0,05)$ itu berarti penolakan terjadi H0 yang menunjukkan strategi komunikasi memiliki korelasi dengan jumlah konsumen pada "Tour Travel Dita" di Madiun. Hasil uji berikutnya juga diperoleh dari Fisher, nilai Fhitung adalah 49.053 sedangkan Ftabel menunjukkan nilai 4.130, nilai lain Sighit adalah 0,000 sedangkan Sigprob 0,05 . Hal ini berarti nilai Fhitung $\geq$ Ftabel $(49.053 \geq 4130)$ atau Sighit $\leq \operatorname{Sigprob}(0,000 \leq$ 0,05 ) yang berarti penolakan terjadi $\mathrm{H} 0$ menunjukkan pengaruh tentang strategi komunikasi untuk kuantitas konsumen pada "Tour Travel Dita" di Madiun. Dari hasil tes lainnya untuk uji t, nilai thitung adalah 7.004 sedangkan ttabel menunjukkan nilai 1.691, yang berarti nilai Sighit adalah 0,000 atau Sigprob 0,05. Penolakan menunjukkan terjadi H0 yang menunjukkan ada yang berbeda dari strategi komunikasi untuk kuantitas konsumen pada "Tour Travel Dita" di Madiun. Hasil R2 menunjukkan nilai 0.591 artinya menunjukkan prosentase variabel $59,1 \%$ dari jumlah konsumen dipengaruhi oleh strategi komunikasi, sedangkan dari sisa $40,9 \%$ dipengaruhi oleh faktor lain.
\end{abstract}

KataKunci: Strategi Komunikasi, Quantity Konsumen.

\section{Pendahuluan}

Setiap perusahaan berusaha menciptakan strategi komunikasi agar berada di benak konsumen, begitu pula dengan perusahaan travel yang berusaha menciptakan komunikasi yang baik di mata masyarakat. Komunikasi juga dapat digunakan sebagai pengingat bagi konsumen mengenai keberadaan pelayanan jasa travel. Proses komunikasi yang bersifat mengingatkan ini sangat penting artinya bagi kelangsungan hidup perusahaan.
Komunikasi menurut Carl I. Holvand dalam Nugroho J. Setiadi. (2003:239) Communation is the process by which individual (the communicator) transmits stimuly (usually verbal symbols) to modify the behavior of other of other individuals. Komunikasi adalah proses dimana seseorang individu (komunikator) mengoperkan perangsang (biasanya lambang-lambang bahasa) untuk merubah tingkah laku (komunikan).

Dalam strategi komunikasi secara online perusahaan Dita Tour Travel ini dalam 
memasarkan jasanya melalui Facebook dan Email. Sedangkan dalam memasarkan jasa secara langsung perusahaan ini menggunakan strategi komunikasi menggunakan Brosur dan Spanduk.

Perusahaan perseorangan adalah suatu bentuk perusahaan yang dijalankan seseorang yang merupakan pemilik, pemimpin, pengusaha dan juga pengelola (M.Th. Kuswariningsih 2009:23). Jadi segala sesuatunya tergantung pada kemampuan dirinya sendiri. Apabila perusahaan memperoleh keuntungan, maka semua akan menjadi miliknya. Sebaliknya, bila terjadi kerugian ia harus menanggungnya sendiri.

Badan usaha yang didirikan pada Dita Tour Travel merupakan badan usaha perseorangan. Usaha yang didirikannya sebuah usaha jasa travel, dimana badan usaha ini melayani jasa travel berupa mobil maupun bus untuk tour. Perusahaan ini selain melayani jasa tour dan travel, juga melayani penjualan tiket pesawat maupun tiket kapal.

Dengan semakin kritisnya penggunaan dalam memilih suatu jasa serta menyadari pentingnya mengetahui tanggapan pengguna terhadap kualitas layanan yang diberikan, mendorong badan usaha untuk selalu memberikan layanan yang diberikan, kualitas yang dapat memuaskan konsumen, kegiatan promosi yang tepat, harga yang bersaing, kenyamanan yang diberikan dan sebagainya.

Konsumen menyenangi dan memberikan penilaian yang positif terhadap jasa yang memiliki kualitas yang baik dan memiliki keistimewaan tersendiri. Hal ini dapat mendorong konsumen untuk melakukan aktivitas penggunaan jasa travel tersebut dalam rangka memuaskan kebutuhan dan keinginannya, sehingga tujuan dari perusahaan dapat tercapai. Seperti meningkatkan jumlah konsumen, meningkatkan kemampuan bersaing, meningkatkan kepuasan konsumen dalam menggunakan jasa travel tersebut.

Apabila dikaitkan dengan strategi komunikasi secara menyeluruh denyut nadi keberhasilan atau perusahaan dan kelangsungan hidup perusahaan itu sendiri adalah berhasil tidaknya strategi komunikasi yang dilakukan. Dan oleh karena itu kepuasan konsumen dan jumlah konsumen adalah salah satu faktor keberhasilan perusahaan. Dengan menyerasikan antara produk jasa yang ditawarkan dan kebutuhan pasar, mereka akan mengetahui kelemahan produknya, jasanya dan perkembangan kebutuhan konsumen.

Menurut Ujang Sumarwan (2011:1) Konsumen adalah (a) pelanggan, pemakai, pengguna, pembeli, pengambil keputusan, (b) Barang, jasa, merek, harga, kemasan, kualitas, kredit, toko, layanan purna jual, (c) menawar, mencari informasi, membandingkan merek, (d) persepsi, preferensi, sikap, loyalitas, kepuasan, motivasi, gaya hidup.

Sedangkan dalam Pasal 1 ayat 2 Undang-Undang Nomor 8 tahun 1999 tentang Perlindungan Konsumenmemberikan pengertian konsumen adalah setiap orang pemakai barang dan atau jasa yang tersedia dalam masyarakat, baik untuk kepentingan diri sendiri, keluarga, orang lain maupun mahluk hidup lain yang tidak untuk diperdagangkan.

Dari pihak lain konsumen menurut Philip Kotler (2000) dalam Prinsiples Of Marketing adalah semua individu dan rumah tangga yang membeli atau memperoleh barang atau jasa untuk dikonsumsi pribadi. Keputusan pembelian dari pembeli sangat dipengaruhi oleh faktor kebudayaan, sosial, pribadi dan psikologi dari pembeli. Sebagian besar adalah faktor-faktor yang tidak dapat dikendalikan oleh pemasar, tetapi harus benar-benar diperhitungkan.

Pengembangan pemasaran dalam hal ini lebih diarahkan untuk dapat memenuhi kebutuhan dan keinginan konsumen. Oleh beberapa ahli, konsumen atau pelanggan disebut pasar atau pasar sasaran bagi perusahaan. Untuk meningkatkan jumlah konsumen atau pelanggan, perusahaan harus 
memberikan produk serta jasa atau pelayanan yang memuaskan. Oleh karena itu perlu adanya suatu upaya yang harus ditempuh oleh organisasi atau perusahaan untuk mempengaruhi konsumen atau pelanggan dalam membeli suatu produk yang ditawarkan dengan melihat kombinasi 4 faktor. bahwa kombinasi 4 faktor terdiri dari:

1) Menawarkan sesuatu yang bernilai bagi konsumen baik itu berupa barang maupun jasa.

2) Menetapkan harga produk yang wajar, artinya penjual dan pembeli dapat saling memperoleh manfaat dari produk tersebut.

3) Berusaha untuk mengkomunikasikan atau melakukan promosi atas manfaat produk yang dihasilkan kepada target pasar yang akan dilayani.

4) Merancang model distribusi yang mampu menjamin ketersediaan produk diberbagai tempat dan situasi.

Pelanggan merupakan aset terbesar bagi suatu perusahaan, tanpa pelanggan maka suatu perusahaan tidak akan pernah ada. Pelayanan yang berkualitas terhadap pelanggan merupakan kunci utama untuk meraih sukses dalam jangka panjang. Bila sebuah perusahaan ingin berhasil dalam jangka panjang maka usaha-usaha untuk memelihara konsumen melalui pelayanan yang memuaskan harus memperoleh perhatian yang utama.Seberapa besar tambahan profit yang diperoleh dengan pertambahan jumlah konsumen baru, jangan sampai konsumen yang baru merupakan konsumen yang sifatnya coba-coba atau konsumen yang peka harga, yang hanya pindah ke produk kita saat dilakukan promosi. Bila hal ini terjadi perolehan tambahan pangsa pasar sifatnya hanya sesaat yaitu pada periode promosi saja.

Kesetiaan pelanggan dapat diciptakan melalui customer relantionship marketing, yang berarti menjaga hubungandengan pelanggan dengan memberikan pelayanan yang berkualitas merupakan kunci keberhasilan jangka panjang. Dalam kaitannya ini ada lima tingkatan jalinan hubungan yang bisa dibina antara produsen dengan pelanggan, yaitu sebagai berikut : (1) Basic, para penjual hanya menjual produk dan sama sekali tidak melakukan kontak setelah pembelian terjadi. (2) Reactive, penjual menjual produk dan menyarankan agar mengontak mereka bila ada yang perlu ditanyakan pelanggan. (3) Accountable, penjual mengontak pelanggan beberapa saat setelah penjualan terjadi untuk memastikan apakah produk ini sudah sesuai dengan harapan mereka. (4) Proactive, tenaga penjual melakukan kontak dengan pelanggan setiap saat untuk memaastikan bahwa tidak terjadi gangguan dalam penggunaan produknya serta menginformasikan adanya produk baru. (5) Partnership, pihak penjual bekerja sama secara kontinyu dengan pelanggan untuk menemukan suatu cara agar pelanggan bisa menjadi lebih baik.

Menurut Griffin, (2000) (dalam Ernie Tisnawati Sule \& Kurniawan Saefullah 2005:132) mendefinisikan strategi sebagai rencana komprehensif untuk mencapai tujuan organisasi. (Strategy is a comprehensif plan for accomplishing anorganization's goals). Tidak hanya sekadar mencapai, akan tetapi strategi juga dimaksudkan untuk mempertahankan keberlangsungan organisasi di lingkungan di mana organisasi tersebut menjalankan aktivitasnya. Bagi organisasi bisnis, strategi dimaksudkan untuk mempertahankan keberlangsungan bisnis perusahaan dibandingkan para pesaingnya dalam memenuhi kebutuhan konsumen.

Sedangkan menurut Boyd, Walker, Larreeche (2000:29) "Strategi adalah pola fundamental dari tujuan sekarang dan yang direncanakan, pengerahan sumber daya, dan interaksi dari organisasi dengan pasar, pesaing, dan faktor-faktor lingkungan lain".

Di lain pihak Lawrence R.Jauch dan William F. Glueck (1988:12) "Strategi adalah rencana yang disatukan, menyeluruh dan terpadu yang mengaitkan keunggulan strategi 
perusahaan dengan tantangan lingkungan dan yang dirancang untuk memastikan bahwa tujuan utama perusahaan dapat dicapai melalui pelaksanaan yang tepat oleh perusahaan".

Menurut Griffin (2000) dalam Ernie Tisnawati Sule \& Kurniawan Saefullah (2005:133), bahwa secara umum strategi dapat dibagi menjadi dua jenis dilihat dri tingkatannya. (1) Strategi pada tingkat perusahaan (corparate-level strategy). (2) Strategi pada tingkat bisnis (bussineslevel strategy). Strategi pada level perusahaan atau korporat dilakukan perusahaan sehubungan dengan persaingan antar perusahaan dalam sektor bisnis yang dijalankannya secara keseluruhan. (3) Strategi pada tingkat fungsional (functional level strategy).

Menurut Carl I. Hovland dalam Nugroho J.Setiadi, (2003-239) Science of communication is a systematic attempt to formulate in rigorous the principle by which information in transmited and opinions and attiludes formed. Ilmu komunikasi adalah suatu sistem yang berusaha menyusun prinsip-prinsip dalam bentuk yang tepat mengenai hal memindahkan penerangan dan membentuk pendapat serta sikap-sikap.

Mengenai komunikasi Carl I. Holvand mengemukakan:Communication is the process by which individual the communicator) transmitsstimuly (usually verbal symbols) to modify the behavior of other of other individuals. Komunikasi adalah proses dimana seseorang individu (komunikator) mengoperkan perangsang (biasanya lambang-lambang bahasa) untuk merubah tingkah laku (komunikan).

Sedangkan William Albig dalam Nugroho J.Setiadi (2003-240) menyatakan "Communication is the process of transmitting meaningful symbols between individuals. Komunikasiadalah proses pengoperan lambang-lambang yang berarti di antara individu-individu".

Di lain pihak Sir Geral Barry dalam Nugroho J. Setiadi (2003:240) Istilah "communacation" berasal dari perkataan lain "communicate" artinya to talk together, confer, discourse and consult with another yang kira-kira artinya berunding. Selanjutnya Sir Geral Berry mengemukakan bahwa dengan komunikasi orang memperoleh pengetahuan, informasi dan pengalaman, karena itu maka saling mengerti, percakapan, keyakinan, kepercayaan dan kontrol sangat diperlukan.

\section{Strategi Komunikasi}

Menurut Onong Uchjana Effendi dalam buku berjudul "Dimensi-dimensi Komunikasi” (1981:84) menyatakan bahwa:"Strategi komunikasi merupakan panduan dari perencanaan komunikasi (communication planning) dan manajemen (communications management) untuk mencapai suatu tujuan. Untuk mencapai tujuan tersebut strategi komunikasi harus dapat menunjukkan bagaimana operasionalnya secara taktis harus dilakukan,dalam arti kata bahwa pendekatan (approach) bisa berbeda sewaktu-waktu tergantung dari situasi dan kondisi”.

Sedangkan Anwar Arifin dalam buku "Strategi Komunikasi" (1984:10) menyatakan bahwa :"Sesungguhnya suatu strategi adalahkeseluruhan keputusan kondisional tentang tindakan yang akan dijalankan, guna mencapai tujuan. Jadi merumuskan strategi komunikasi, berarti memperhitungkan kondisi dan situasi (ruang dan waktu) yang dihadapi dan yang akan mungkin dihadapi di masa depan, guna mencapai efektivitas. Dengan strategi komunikasi ini, berarti dapat ditempuh beberapa cara memakai komunikasi secara sadar untuk menciptakan perubahan pada diri khalayak dengan mudah dan cepat".

Menurut Yazid (2004:98) bahwa strategi-strategi komunikasi terdiri dari: (1) Menuntun kepada kelompok konsumen mana yang akan disasar, yang paling mudah diyakinkan bahwa produk yang ditawarkan itu penting bagi mereka. (2) Menuntun pemilihan pesan-pesan apa yang harus 
disampaikan (menentukan atribut mana yang harus ditekankan dan kompetitor mana yang harus dijadikan patokan pembanding dari atribut-atribut yang di tonjolkan). (3) Menjadi pedoman bagi pemilihan saluran komunikasi - apakah melalui tenaga penjualan atau media periklanan yang lain? (Yang dipilih bukan hanya karena kemampuannya dalam menyampaikan pesan kepada para konsumen di pasar target, tetapi juga karena kemampuannya dalam memperkuat image konsumen terhadap produk yang mereka inginkan.

Fandy Tjiptono (2005:249) "perancangan strategi komunikasi pemasaran jasa berbeda dengan komunikasi barang fisik dalam lima faktor utama yakni; karakteristik intangibility pada kinerja jasa; keterlibatan pelanggan dalam produksi jasa; manajemen penawaran dan permintaan; peranan strategis staf kontak pelanggan; dan berkurangnya peran perantara". (1) Karakteristik intangibility pada kinerja jasa. Jasa lebih bersifat kinerja (performance) daripada objek, sehingga pemasar jasa harus mampu mencari cara-cara membuat jasanya lebih konkret dan mengklarifikasi tipe kinerja yang bisa diberikan. (2) Keterlibatan pelanggan dalam produksi jasa. Tekanan untuk meningkatkan produktifitas dalam organisasi jasa sering menyebabkan dibutuhkannya perubahan yang signifikan dalam sistem penyampaian jasa, terutama menyangkut pemanfaatan inovasi teknologi. (3) Manajemen penawaran dan permintaan. Implikasi dari karakteristik perishability jasa, yakni jasa tidak bisa disimpan. Iklan dan promosi penjualan bisa membantu pemasar jasa untuk membentuk permintaan agar selaras dengan ketersediaan kapasitas jasa pada periode waktu spesifik. Strategi manajemen permintaan, seperti mengurangi pemakaian pada saat permintaan puncak dan menstimulasi pemakaian pada periode permintaan sepi, bisa diterapkan secara efektif melalui program promosi penjualan dan periklanan. (4) Peranan strategis staf kontak pelanggan. Pada jasa kontak tinggi, karyawan jasa merupakan faktor sentral dalam penyampaian jasa. Kehadiran mereka membuat jasa lebih tangible dan dalam banyak kasus, juga lebih perzonalized. (5) Berkurangnya peran perantara. Salah satu perbedaan signifikan antara barang dan jasa, yakni pemanfaatan perantara pada sektor jasa tidak sesering atau sebanyak pada sektor manufaktur.

Strategi komunikasi dalam pemasaran jasa sangat berpengaruh terhadap jumlah konsumen. Jika cara yang disampaikan dalam memasarkan jasa lebih koefisien, maka kemungkinan jumlah konsumen juga semakin meningkat. Hal ini dikarenakan ketersediaan komunikator memasarkan produk jasa kepada konsumen secara efektif.

Dalam strategi komunikasi yang menjadi acuan agar perusahaan tetap dapat bertahan dalam jangka waktu panjang salah satunya adalah semakin banyaknya jumlah konsumen yang datang untuk menggunakan jasa travel pada perusahaan Dita Tour Travel tersebut. Dengan adanya strategi komunikasi tersebut maka perusahaan dapat meningkatkan kualitas serta pelayanannya.

Fiske dan Heartley dalam Philip Kotler (2005:250) telah menjelaskan "ada beberapa faktor umum yang mempengaruhi efektivitas komunikasi salah satunya adalah makin besar pengaruh sumber komunikasi terhadap penerimanya, makin besar pula bahan atau pengaruhnya terhadap penerima tersebut yang menguntungkan sumber".

Perkembangan jumlah konsumen suatu perusahaan pada dasarnya tergantung dari berbagai faktor. Salah satunya dengan strategi komunikasi. Dengan adanya strategi komunikasi maka perusahaan akan berkembang lebih maju dan bisa sampai jangka waktu panjang serta perkembangan jumlah konsumen juga pesat.

\section{Metode Penelitian}

Tempat Penelitian dilakukan di Dita Tour Travel yang berlokasi di Jl. Letjen S. Parman 38 B Madiun. Penelitian dilakukan 
selama 4 bulan pada bulan Februari 2013 sampai dengan Mei 2013.Rancangan penelitian yang digunakan dalam penelitian ini adalah penelitian kausal-komparatif. Tujuan penelitian kausal- komparatif adalah untuk menyelidiki kemungkinan hubungan kausal atau sebab-akibat berdasarkan pengamatan terhadap akibat yang ada. Ciri- ciri penelitian kausal-komparatif adalah bersifat ex post facto artinya data dikumpulkan setelah semua kejadian yang akan ditelitii berlangsung (Usman dan Abdi, 2009:35).

Variabel dalam penelitian ini yang menjadi variabel bebas $(\mathrm{X})$ adalah strategi komunikasi. sedang variabel terikatnya (Y) adalah jumlah konsumen.

Dalam penelitian ini yang menjadi populasi adalah 72 Bulan yang diambil dari Bulan Januari 2007 s/d Bulan Desember 2012 pada "Dita Tour Travel" di Madiun.Sampel merupakan bagian dari populasi. Suharsimi Arikunto (2010:174) menyatakan "sampel adalah sebagian atau wakil populasi yang diteliti”. Sampel dalam penelitian ini yaitu 36Bulan. Diperoleh dari dokumentasi berupa data penjualan online dan langsung di Dita Tour Travel Madiun pada Bulan Januari 2010s/d Bulan Desember 2012. Peneliti mengambil data berupa dokumentasi daftar jumlah konsumen secara online dan langsung sebagai subyek penelitian pada Bulan Januari 2010s/d Bulan Desember 2012.

Dalam penelitian ini teknik pengumpulan data yang digunakan adalah: Dokumentasi, Metode ini dipergunakan untuk mendapatkan data tentang strategi komunikasi dan jumlah konsumen yang diperoleh dari buku, dan catatan harian yang ada pada "Dita Tour Travel” di Madiun.

\section{Hasil Penelitian}

Deskripsi variabel strategi komunikasi dengan jumlah data $(\mathrm{N})$ sebanyak 36 mempunyai deskripsi data sebagai berikut: (a) jumlah skor total sebesar 5034; (b) nilai rata-rata hitung (mean) sebesar 139,83; (c) median sebesar 140,00; (d) modus sebesar
146; (e) standar deviasi sebesar 9,907; (f) nilai minimum sebesar 112; (g) nilai maximum sebesar 159. Dari analisis deskriptif di atas dapat dikatakan strategi komunikasi "Dita Tour Travel" di Madiun baik, karena strategi komunikasi pada "Dita Tour Travel" di Madiun mempunyai nilai di atas rata-rata sebanyak 20 bulan yaitu 55,56\%. Sedangkan nilai di bawah rata-rata sebanyak 16 bulan yaitu $44,44 \%$.

Deskripai variabel jumlah konsumen dengan jumlah data $(\mathrm{N})$ sebanyak 36 mempunyai deskripsi data sebagai berikut: (a) jumlah skor total sebesar 10234; (b) nilai rata-rata hitung (mean) sebesar 284,28; (c) median sebesar 281,50; (d) modus sebesar 280; (e) standar deviasi sebesar 14,601; (f) nilai minimum sebesar 257; (g) nilai maximum sebesar 316. Dari analisis deskriptif di atas dapat dikatakan jumlah konsumen pada "Dita Tour Travel" di Madiun baik, karena jumlah konsumen mempunyai nilai di atas rata-rata sebanyak 22 bulan yaitu $61,11 \%$. Sedangkan nilai di bawah rata-rata sebanyak 14 bulan yaitu $38,89 \%$.

Dari penelitian diketahui bahwa besarnya nilai $r_{\text {hitung }}$ adalah 0,769 sedangkan $\mathrm{r}_{\text {tabel }}$ 0,329. Selain itu nilai $\mathrm{Sig}_{\text {hit }}$ adalah 0,000 sedangkan $\operatorname{Sig}_{\text {prob }} 0,05$. Hal ini berarti bahwa nilai $r_{\text {hitung }} \geq r_{\text {tabel }}(0,769 \geq 0.329)$ atau $\operatorname{Sig}_{\text {hit }} \leq \operatorname{Sig}_{\text {prob }}(0,000 \leq 0,05)$. Atas dasar uji korelasi tersebut dapat disimpulkan tolak $\mathrm{H}_{0}$, artinya ada hubungan strategi komunikasi dengan jumlah konsumen pada Dita Tour Travel di Madiun Bulan Januari 2010 - Bulan Desember 2012.Dilain pihak dalam uji determinasi yang diperoleh nilai $R^{2}(R$ Square) atau koefisien determinasi yang digunakan untuk mengetahui seberapa besar prosentase sumbangan strategi komunikasi terhadap jumlah konsumen. Berdasarkan tabel 4.6. tersebut di atas dapat diketahui nilai $\mathrm{R}^{2}$ adalah 0,591. Jadi sumbangan pengaruh dari strategi komunikasi terhadap jumlah konsumen yaitu 59,1\% sedangkan sisanya sebesar $40,9 \%$ dipengaruhi oleh faktor 
lain.Uji Fisher dipengaruhi besarnya nilai $F_{\text {hitung }}$ adalah 49,053 sedangkan $F_{\text {tabel }}$ sebesar 4,130 , dilain pihak besarnya $\mathrm{Sig}_{\text {hit }}$ adalah 0,000 sedangkan $\operatorname{Sig}_{\text {prob }}$ 0,05. Hal ini berarti bahwa nilai $F_{\text {hitung }} \geq \mathrm{F}_{\text {tabel }}(49,053 \geq 4,130)$ atau $\operatorname{Sig}_{\text {hit }} \leq \operatorname{Sig}_{\text {prob }}(0,000 \leq 0,005)$. Atas dasar uji Fisher tersebut dapat disimpulkan tolak $\mathrm{H}_{0}$, artinya ada pengaruh strategi komunikasi terhadap jumlah konsumen pada "Dita Tour Travel di Madiun" Bulan Januari 2010 Bulan Desember 2012. Selain digunakan untuk mencari pengaruh, uji Fisher atau Anova bisa juga digunakan untuk menguji linearitas. Karena $\mathrm{F}_{\text {hitung }}$ sebesar $49,053 \geq \mathrm{F}_{\text {tabel }}$ sebesar 4,130, berarti ada hubungan yang linier antara variabel strategi komunikasi dengan jumlah konsumen. Persamaan garis regresi sebagai berikut: $\mathrm{Y}=125,895+$ $1,133 \mathrm{X}$, artinya adalah apabila strategi komunikasi ditingkatkan satu kali akan terjadi kenaikan strategi komunikasi sebanyak $1,133 \%$, apabila faktor lainnya tetap. Selanjutnya dari tabel 4.8. di atas dapat diketahui bahwa nilai $t_{\text {hitung }}$ adalah 7,004 sedangkan $t_{\text {tabel }}$ sebesar 1,691, dilain pihak nilai $\mathrm{Sig}_{\text {hit }}$ adalah 0,000 sedangkan $\operatorname{Sig}_{\text {prob }} 0,05$. Hal ini berarti bahwa nilai $t_{\text {hitung }} \geq t_{\text {tabel }}(7,004 \geq$ $1,691)$ atau $\operatorname{Sig}_{\text {hit }} \leq \operatorname{Sig}_{\text {prob }}(0,000 \leq 0,05)$. Atas dasar uji $\mathrm{t}$ tersebut dapat disimpulkan tolak $\mathrm{H}_{0}$, artinya ada beda pengaruh strategi komunikasi terhadap jumlah konsumen pada "Dita Tour travel" di Madiun Bulan Januari 2010 - Bulan Desember 2012.

\section{Hasil Analisis}

1. Simpulan Uji korelasi

Hasil dari pengujian korelasi dapat diperoleh besarnya nilai $r_{\text {hitung }}$ adalah 0,769 sedangkan $\mathrm{r}_{\text {tabel }}$ 0,329. Selain itu nilai $\mathrm{Sig}_{\text {hit }}$ adalah 0,000 sedangkan $\operatorname{Sig}_{\text {prob }}$ 0,05. Hal ini berarti bahwa nilai $r_{\text {hitung }} \geq r_{\text {tabel }}(0,769 \geq$ $0.329)$ atau $\operatorname{Sig}_{\text {hit }} \leq \operatorname{Sig}_{\text {prob }}(0,000 \leq 0,05)$. Selain itu diperoleh nilai $\mathrm{R}^{2}$ adalah 0,591 . Jadi sumbangan pengaruh dari strategi komunikasi terhadap jumlah konsumen yaitu $59,1 \%$.Sesuai hipotesis yang diajukan dapat diperoleh simpulan bahwa ada hubungan strategi komunikasi dengan jumlah konsumen pada "Dita Tour Travel" di Madiun Bulan Januari 2010 Bulan Desember 2012. Berarti $\mathrm{H}_{0}$ ditolak, Simpulan Uji Fisher. Hasil dari pengujian Fisher dengan uji Anova dapat diperoleh nilai $\mathrm{F}_{\text {hitung }}$ adalah 49,053 sedangkan $F_{\text {tabel }}$ sebesar 4,130 , dilain pihak besarnya Sig $_{\text {hit }}$ adalah 0,000 sedangkan Sig prob 0,05. Hal ini berarti bahwa nilai $\mathrm{F}_{\text {hitung }} \geq \mathrm{F}_{\text {tabel }}$ $(49,053 \geq 4,130)$ atau $\operatorname{Sig}_{\text {hit }} \leq \operatorname{Sig}_{\text {prob }}(0,000$ $\leq 0,005)$. Sesuai hipotesis yang diajukan dapat diperoleh simpulan bahwa ada pengaruh strategi komunikasi terhadap jumlah konsumen pada "Dita Tour Travel" di Madiun Bulan Januari 2010 Bulan Desember 2012.

2. Simpulan Uji t

Dari hasil perhitungan atau pengujian yang dilakukan diperoleh persamaan regresi sebagai berikut: $\mathrm{Y}=125,895+$ 1,133X, simpulannya adalah apabila strategi komunikasi ditingkatkan satu kali akan terjadi kenaikan strategi komunikasi sebanyak $1,133 \%$, apabila faktor lainnya tetap.

Hasil dari uji t dapat diperoleh nilai $\mathrm{t}_{\text {hitung }}$ adalah 7,004 sedangkan $\mathrm{t}_{\text {tabel }}$ sebesar 1,691, dilain pihak nilai $\operatorname{Sig}_{\text {hit }}$ adalah 0,000 sedangkan $\operatorname{Sig}_{\text {prob }}$ 0,05. Hal ini berarti bahwa nilai $t_{\text {hitung }} \geq t_{\text {tabel }}(7,004 \geq 1,691)$ atau $\operatorname{Sig}_{\text {hit }} \leq \operatorname{Sig}_{\text {prob }}(0,000 \leq 0,05)$. Sesuai hipotesis yang diajukan dapat diperoleh simpulan bahwa ada beda pengaruh strategi komunikasi terhadap jumlah konsumen pada "Dita Tour Travel" di Madiun Bulan Januari 2010 - Bulan Desember 2012 Berarti $\mathrm{H}_{0}$ ditolak.

\section{Pembahasan}

Hasil penelitian menunjukkan bahwa strategi komunikasi berpengaruh terhadap 
jumlah konsumen. Hal ini menunjukkan bahwa strategi komunikasi diperlukan untuk membantu meningkatkan penjualan secara online dan langsung.

Selanjutnya adalah pembahasan untuk uji regresi (uji korelasi, uji Fisher, dan uji t):

1. Pembahasan Uji Korelasi

Untuk uji korelasi diperoleh nilai $\mathrm{r}_{\text {hitung }}$ adalah 0,769 sedangkan $\mathrm{r}_{\text {tabel }} 0,329$, dilain pihak besarnya $\mathrm{Sig}_{\text {hit }}$ adalah 0,000 sedangkan $\operatorname{Sig}_{\text {prob }} 0,05$. Hal ini berarti bahwa nilai $r_{\text {hitung }} \geq r_{\text {tabel }}(0,769 \geq 0.329)$ atau $\operatorname{Sig}_{\text {hit }} \leq \operatorname{Sig}_{\text {prob }}(0,000 \leq 0,05)$. Dengan demikian $\mathrm{H}_{0}$ ditolak, artinya ada hubungan strategi komunikasi dengan jumlah konsumen pada Dita Tour Travel di Madiun Bulan Januari 2010 - Bulan Desember 2012.

Nilai $\mathrm{R}^{2}$ yang diperoleh adalah sebesar 59,1\%. Menunjukkan bahwa strategi komunikasi mempengaruhi jumlah konsumen sebanyak 59,1\%.

2. Pembahasan Uji Fisher

Untuk uji Fisher diperoleh nilai $\mathrm{F}_{\text {hitung }}$ adalah 49,053 sedangkan $F_{\text {tabel }}$ sebesar 4,130 , di lain pihak besarnya $\operatorname{Sig}_{\text {hit }}$ adalah 0,000 sedangkan $\mathrm{Sig}_{\text {prob }}$ 0,05. Hal ini berarti bahwa nilai $F_{\text {hitung }} \geq F_{\text {tabel }}(49,053 \geq$ $4,130)$ atau $\operatorname{Sig}_{\text {hit }} \leq \operatorname{Sig}_{\text {prob }}(0,000 \leq 0,005)$. Dengan demikian $\mathrm{H}_{0}$ ditolak, artinya ada pengaruh strategi komunikasi terhadap jumlah konsumen pada "Dita Tour Travel di Madiun" Bulan Januari 2010 - Bulan Desember 2012.

3. Pembahasan Ujit

Dapat dilihat pada hasil persamaan regresi sebagai berikut: $\mathrm{Y}=125,895+$ $1,133 \mathrm{X}$, artinya adalah apabila strategi komunikasi ditingkatkan satu kali akan terjadi kenaikan strategi komunikasi sebanyak $1,133 \%$, apabila faktor lainnya tetap.

Untuk uji $\mathrm{t}$ diperoleh nilai $\mathrm{t}_{\text {hitung }}$ adalah 7,004 sedangkan $\mathrm{t}_{\text {tabel }}$ sebesar 1,691, dilain pihak nilai $\operatorname{Sig}_{\text {hit }}$ adalah 0,000 sedangkan $\operatorname{Sig}_{\text {prob }}$ 0,05. Hal ini berarti bahwa nilai $t_{\text {hitung }} \geq t_{\text {tabel }}(7,004 \geq 1,691)$ atau $\operatorname{Sig}_{\text {hit }} \leq \operatorname{Sig}_{\text {prob }}(0,000 \leq 0,05)$. Dengan demikian $\mathrm{H}_{0}$ ditolak, artinya ada beda pengaruh strategi komunikasi terhadap jumlah konsumen pada "Dita Tour travel" di Madiun Bulan Januari 2010 - Bulan Desember 2012.

Dari hasil penelitian menunjukkan bahwa strategi komunikasi mempunyai hubungan sekaligus pengaruh terhadap jumlah konsumen. Artinya strategi komunikasi yang diterapkan pada perusahaan untuk menarik jumlah konsumen, dan menjadikan konsumen meningkat.

Hal ini sesuai dengan teori Fandy Tjiptono (2005:249) "perancangan strategi komunikasi pemasaran jasa berbeda dengan komunikasi barang fisik dalam lima faktor utama yakni; karakteristik intangibility pada kinerja jasa; keterlibatan pelanggan dalam produksi jasa; manajemen penawaran dan permintaan; peranan strategis staf kontak pelanggan; dan berkurangnya peran perantara".

Strategi pada hakekatnya adalah perencanaan (planning) dan manajemen (management) untuk mencapai tujuan. Namun, untuk mencapai tujuan tersebut, strategi tidak berfungsi sebagai peta jalan yang hanya menunjukkan arah saja, tapi harus menunjukkan bagaimana taktik operasionalnya.

Strategi komunikasi dalam pemasaran jasa sangat berpengaruh terhadap jumlah konsumen. Jika cara yang disampaikan dalam memasarkan jasa lebih koofisien, maka kemungkinan jumlah konsumen juga semakin meningkat. Hal ini dikarenakan ketersediaan komunikator memasarkan produk jasa kepada konsumen secara efektif.

\section{Penutup}

\section{Simpulan}

Strategi komunikasi yang dilaksanakan oleh "Dita Tour Travel” di Madiun baik. Hal 
tersebut dapat dilihat dari data penjualan selama 36 Bulan terhitung dari Bulan Januari 2010 s/d Bulan Desember 2012 pada "Dita Tour Travel" di Madiun. Hal ini sesuai dengan hasil statistik deskriptif variabel strategi komunikasi dengan jumlah data $(\mathrm{N})$ sebanyak 36 mempunyai deskripsi data sebagai berikut: (a) jumlah skor total sebesar 5034; (b) nilai rata-rata hitung (mean) sebesar 139,83; (c) median sebesar 140,00; (d) modus sebesar 146; (e) standar deviasi sebesar 9,907; (f) nilai minimum sebesar 112; (g) nilai maximum sebesar 159. Dari analisis deskriptif di atas dapat dikatakan strategi komunikasi "Dita Tour Travel" di Madiun baik, karena strategi komunikasi pada "Dita Tour Travel" di Madiun mempunyai nilai di atas rata-rata sebanyak 20 bulan yaitu 55,56\%. Sedangkan nilai di bawah rata-rata sebanyak 16 bulan yaitu $44,44 \%$.

Jumlah konsumen pada "Dita Tour Travel" di Madiun dapat dikatakan baik. Hal tersebut dapat dilihat dari data penjualan selama 36 Bulan terhitung dari Bulan Januari 2010 s/d Bulan Desember 2012 pada "Dita Tour Travel" di Madiun. Hal ini sesuai dengan hasil statistik deskriptif variabel strategi komunikasi dengan jumlah data $(\mathrm{N})$ sebanyak 36 mempunyai deskripsi data sebagai berikut:(a) jumlah skor total sebesar 10234; (b) nilai rata-rata hitung (mean) sebesar 284,28; (c) median sebesar 281,50; (d) modus sebesar 280; (e) standar deviasi sebesar 14,601; (f) nilai minimum sebesar 257; (g) nilai maximum sebesar 316. Dari analisis deskriptif di atas dapat dikatakan jumlah konsumen pada "Dita Tour Travel" di Madiun baik, karena jumlah konsumen mempunyai nilai di atas rata-rata sebanyak 22 bulan yaitu $61,11 \%$. Sedangkan nilai di bawah rata-rata sebanyak 14 bulan yaitu $38,89 \%$.

Strategi komunikasi mempunyai pengaruh terhadap jumlah konsumen pada "Dita Tour Travel" di Madiun. Terbukti dari hasil analisis regresi yang memuat uji korelasi, uji F, dan uji t sebagai berikut:

\section{Analisis Uji Determinasi}

Nilai $R^{2}$ (R Square) atau koefisien determinasi yang digunakan untuk mengetahui seberapa besar prosentase sumbangan strategi komunikasi terhadap jumlah konsumen. Diketahui nilai $\mathrm{R}^{2}$ adalah 0,591. Jadi sumbangan pengaruh dari strategi komunikasi terhadap jumlah konsumen yaitu $59,1 \%$ sedangkan sisanya sebesar $40,9 \%$ dipengaruhi oleh faktor lain.

\section{Hasil Uji Korelasi}

Nilai $r_{\text {hitung }}$ adalah 0,769 sedangkan $r_{\text {tabel }}$ 0,329. Selain itu nilai $\mathrm{Sig}_{\text {hit }}$ adalah 0,000 sedangkan $\operatorname{Sig}_{\text {prob }}$ 0,05. Hal ini berarti bahwa nilai $r_{\text {hitung }} \geq r_{\text {tabel }}(0,769 \geq 0.329)$ atau $\operatorname{Sig}_{\text {hit }} \leq$ $\operatorname{Sig}_{\text {prob }}(0,000 \leq 0,05)$, artinya ada hubungan strategi komunikasi dengan jumlah konsumen pada Dita Tour Travel di Madiun Bulan Januari 2010 - Bulan Desember 2012.

\section{Hasil Uji F}

Nilai $F_{\text {hitung }}$ adalah 49,053 sedangkan $F_{\text {tabel }}$ sebesar 4,130, dilain pihak besarnya Sig $_{\text {hit }}$ adalah 0,000 sedangkan $\operatorname{Sig}_{\text {prob }}$ 0,05. Hal ini berarti bahwa nilai $F_{\text {hitung }} \geq F_{\text {tabel }}(49,053 \geq$ 4,130) atau $\operatorname{Sig}_{\text {hit }} \leq \operatorname{Sig}_{\text {prob }}(0,000 \leq 0,005)$, artinya ada pengaruh strategi komunikasi terhadap jumlah konsumen pada "Dita Tour Travel di Madiun" Bulan Januari 2010 Bulan Desember 2012.

\section{Hasil Uji t}

Nilai $t_{\text {hitung }}$ adalah 7,004 sedangkan $t_{\text {tabel }}$ sebesar 1,691, di lain pihak nilai $\mathrm{Sig}_{\mathrm{hit}}$ adalah 0,000 sedangkan $\operatorname{Sig}_{\text {prob }}$ 0,05. Hal ini berarti bahwa nilai $\mathrm{t}_{\text {hitung }} \geq \mathrm{t}_{\text {tabel }}(7,004 \geq 1,691)$ atau $\operatorname{Sig}_{\text {hit }} \leq \operatorname{Sig}_{\text {prob }}(0,000 \leq 0,05)$, artinya ada beda pengaruh strategi komunikasi terhadap jumlah konsumen pada "Dita Tour travel" di Madiun Bulan Januari 2010-Bulan Desember 2012.

\section{Saran}

\section{Bagi Perusahaan}

Bagi perusahaan seharusnya melakukan evaluasi khususnya dalam bidang strategi 
komunikasi yang telah dilakukan. Merencanakan strategi komunikasi yang bertujuan untuk meningkatkan jumlah konsumen. Selain itu untuk strategi komunikasi melalui internet, sebaiknya "Dita Tour Travel" membuat website khusus, sehingga sarana promosi dan penjualan yang diberikan lebih lengkap dan mudah untuk dijangkau oleh khalayak luas.

\section{Bagi Peneliti Mendatang}

Bagi peneliti yang selanjutnya, sebaiknya perlu menambah atau mencari variabel lain yang dapat mengembangkan penelitian ini. Selain itu juga bisa mencari populasi lain atau mengubah populasi dari penelitian ini dengan mengadakan penelitian di tahun tahun yang akan datang. Karena dalam penelitian ini populasinya hanya mengambil tahun 2010-2012.

\section{DAFTAR PUSTAKA}

Aditnobaka. 2010. Pengertian Konsumen. (http://aditnobaka.wordpress.com/201 0/10/08/pengertian-konsumen.html) (diunduh 10-04-13)

Buletin Studi Ekonomi. 2009. Menarik dan Memelihara Pelanggan. (http://jurnalsdm.blogspot.com/2009/03/menarikdan-memelihara-pelanggan_05.html) (diunduh 05-05-13)

Boyd, Walker dan Larreche. 2000. Manajemen Pemasaran. Jakarta: Erlangga.

Cahyadi. 2012. Strategi Komunikasi. (http://cahyadiblogsan.blogspot.com/2 012/02/strategi-komunikasi.html) (diunduh 10-04-13)

Duwi Priyatno. 2010. Teknik Mudah Dan Cepat Melakukan Analisis Data Penelitian SPSS. Yogyakarta: Gava Media.
Ernie Tisnawati Sule dan Kurniawan Saefullah. 2005. Pengantar Manajemen. Jakarta: Prenada Media Group.

Fandy Tjiptono. 2005. Pemasaran Jasa. Malang: Bayumedia Publlshing.

Gabriel Amin Silalahi. 2003. Metodologi Penelitian Dan Studi Kasus. Sidoarjo: Citra Media.

Husein umar. 2011. Metode Penelitian Untuk Skripsi dan Tesis Bisnis. Jakarta: PT. Raja Grafindo Persada.

Iqbal Hasan. 2004. Analisis Data Penelitian Dengan Statistik. Jakarta: Bumi Aksara

Juliansyah Noor. 2011. Metodologi Penelitian: Skripsi, Tesis, Disertasi, dan Karya Ilmiah. Jakarta: Prenada Media Group.

J. Supranto. 2008. Statistik: Teori dan Aplikasi. Jakarta: Erlangga.

Lawrence R. Jauch dan William F. Glueck. 1988. Manajemen Strategis Dan Kebijakan Perusahaan. Jakarta: PT. Gelora Aksara Pratama.

Leon Schiffman dan Leslie Lazar Kanuk. 2008. Perilaku Konsumen. Jakarta: PT. Indeks.

Nugroho J. Setiadi. 2003. Perilaku Konsumen. Jakarta: Prenada Media.

Nasution, S. 2004. Metodologi Research: Penelitian Ilmiah. Jakarta: PT. Bumi Aksara.

Philip Kotler. 2005. Manajemen Pemasaran.Jakarta: PT. Indeks.

Sugiyono. 2008. Statistika Untuk Penelitian. Bandung: Alfabeta.

Sumadi Suryabrata. 2012. Metodologi Penelitian. Jakarta: PT. Raja Grafindo Persada.

Suharsimi Arikunto. 2010. Prosedur Penelitian Suatu Pendekatan Praktik. Jakarta: Rineka Cipta. 
Teddy Gartustiadi. 2011. Pengaruh Promosi Penjualan Terhadap Peningkatan Jumlah Tabungan Pada Bank NISP TBK. (http://information4lecture. blogspot.com/2011/04/pengaruhpromosi-penjualan-terhadap.html) (diunduh 05-05-13)

Ujang Sumarwan. 2011. Perilaku Konsumen Teori Dan Penerapannya dalam Pemasaran. Bogor: Ghalia Indonesia.
Undang-Undang Republik Indonesia Nomor 8 Tahun 1999 Tentang Perlindungan Konsumen.

Usman Rianse dan Abdi. 2009. Metodologi Penelitian Sosial dan Ekonomi: Teori dan Aplikasi. Bandung Alfabet.

Yazid. 2004. Pemasaran Jasa Konsep dan Implementasi. Yogyakarta: Ekonisia. 